\title{
Goniothalamin enhances TRAIL-induced apoptosis in colorectal cancer cells through DR5 upregulation and cFLIP downregulation
}

\author{
THANET SOPHONNITHIPRASERT ${ }^{1}$, SIRINUN NILWARANGKOON $^{1}$, \\ YUKIO NAKAMURA $^{2}$ and RAMIDA WATANAPOKASIN ${ }^{1}$
}

\author{
${ }^{1}$ Department of Biochemistry, Faculty of Medicine, Srinkharinwirot University, Bangkok 10110, Thailand; \\ ${ }^{2}$ Department of Orthopaedic Surgery, Shinshu University School of Medicine, Matsumoto 390-8621, Japan
}

Received July 22, 2015; Accepted September 24, 2015

DOI: 10.3892/ijo.2015.3204

\begin{abstract}
The combination of TNF-related apoptosis-inducing ligand (TRAIL) and bioactive compound to enhance apoptosis in TRAIL-resistant cancer is one of cancer treatment strategies. TRAIL possesses the unique capacity to selectively induce apoptosis in cancer cells both in vitro and in vivo with little effect on normal cells. Recent studies have reported that there are many TRAIL-resistant cancers. Thus, bioactive compounds that enhance cytotoxicity of TRAIL would be potential candidates for cancer therapeutic application. This study evaluated the cytotoxic and apoptosis induction upon combined treatment of TRAIL and goniothalamin, the natural styryl-lactone compound extracted from plant Goniothalamus spp., in LoVo cells. The results showed that a combination of goniothalamin and TRAIL enhanced caspase-dependent apoptosis induction in LoVo cells via both death receptor- and mitochondrial-mediated apoptosis pathways. In addition, goniothalamin enhanced TRAIL-induced apoptosis through increased death receptor DR5 expression and decreased anti-apoptotic regulator cFLIP. Interestingly, goniothalamin increased translocation of DR5 to cell surface and consequently contributed to the enhancement of TRAIL-induced apoptosis. In conclusion, this is the first report showing the combined treatment of goniothalamin and TRAIL was able to effectively enhance TRAIL-mediated apoptosis induction in TRAIL-refractory colorectal cancer, LoVo cells. Therefore, this study may offer a strategic cancer treatment against TRAIL-resistant cancers.
\end{abstract}

\section{Introduction}

Tumor necrosis factor-related apoptosis-inducing ligand (TRAIL/APO2L) is a member of the tumor necrosis factor

Correspondence to: Professor Ramida Watanapokasin, Department of Biochemistry, Faculty of Medicine, Srinakharinwirot University, Bangkok 10110, Thailand

E-mail: ramidawa@yahoo.com

Key words: goniothalamin, TRAIL, DR5, cFLIP, apoptosis, colorectal cancer
(TNF) family of cytokines and an effective inducer of apoptosis in cancer cells (1). The interaction of TRAIL with death receptors (DRs), including the death receptors TRAILR1 (also known as DR4 and TNFRSF10A) and TRAILR2 (also known as DR5, KILLER and TNFRSF10B), on the surface of cancer cells can trigger apoptotic cell death signaling through death receptor-mediated apoptosis pathway without any harmful effects to normal cells $(2,3)$. TRAIL binding to DRs causes conformational changes in DRs, which leads to the recruitment of the adaptor protein Fas-associated death domain (FADD) and caspase- 8 and -10 through the cytoplasmic death domain (DD). This forms the so-called death-inducing signaling complex (DISC). Normally, the DISC fully activates caspase- 8 and triggers apoptosis by directly activating the executive caspases, such as caspase- $3,-6$ and -7 , also found in Fas type I cancer cells. However, TRAIL-mediated apoptosis can also induce the mitochondria-mediated apoptosis pathway through the implication of mitochondrial dysfunction and caspase-9 activation via the cleavage of Bid (BH3-interacting domain death agonist) protein into truncated Bid (tBid) by caspase-8. tBid is capable of inducing mitochondrial outer membrane permeabilisation (MOMP) in cells in which the ratio of pro- and anti-apoptotic Bcl-2 family members allows it to do so leading to mitochondrial dysfunction in TRAILtreated cancer cells, also found in Fas type II cancer cells (4-7).

However, some cancer cells are resistant to TRAILinduced apoptosis, especially some highly malignant tumors such as pancreatic cancer, melanoma, neuroblastoma, prostate cancer and colon cancer $(8,9)$. Failure to undergo apoptosis has been implicated in the resistance of cancer cells to TRAIL surveillance and tumor development. The mechanism of resistance to TRAIL-induced apoptosis in cancer can occur at different points in the signaling pathways of TRAIL-induced apoptosis. Dysfunctions or low expression of the DRs can lead to resistance. The defects in FADD and caspase- 8 can lead to TRAIL resistance. Another cause of this defect is the high expression of cellular FADD-like interleukin-1 $\beta$-converting enzyme-inhibitory protein (cFILP) which correlates with TRAIL resistance in several types of cancers because it can bind to FADD and/or caspase-8 and death receptors. This interaction in turn prevents DISC formation and subsequently suppresses the activation of caspase cascade $(10,11)$. High expression of apoptosis inhibitors have been reported to 
result in TRAIL resistance in mitochondria-dependent type II cancer cells (9). Thus, developing strategies to overcome the TRAIL resistance are the topics of interest. Several observations suggest that the combination of TRAIL with effective small molecule compounds can sensitize the resistant cancer to TRAIL-induced apoptosis. Therefore, it has been assumed as strategy to potentiate the cytotoxicity of TRAIL and its therapeutic applications.

The combined compounds synergize TRAIL-induced apoptosis in cancer through two pathways. First, to increase the death receptors DR4/DR5 expression and trigger its translocation to cell membranes thus increasing TRAIL binding resulted in extrinsic apoptosis pathway. Several chemotherapeutic agents and natural compounds, such as CDDP (12), etoposide (13), PS-341 (bortezomib) (14), tunicamycin (15), rottlerin (16), brandisianins (17), sodium butyrate (18), inostamycin (19) were reported to upregulate the death receptor expression and subsequent sensitization of TRAIL-resistant cancer cells to TRAIL-induced apoptosis. Second, resistant mechanism of TRAIL-induced apoptosis is disrupted through downregulation of cFLIP expression. Natural compounds such as kurarinone (20), icaritin (21), withanolide E (22) were reported to downregulate cFLIP expression and subsequent sensitization of TRAIL-resistant cancer cells to TRAIL-induced apoptosis. Natural compounds, such as silibinin (23), gingerol (24) and indomethacin (25) were reported to possess both mechanisms of sensitizing TRAIL-resistant cancer cells.

The LoVo colorectal cancer (CRC) cell line is derived from left supraclavicular region; stage Dukes' C (26). The $\mathrm{CRC}$ is the second most and the third most common cancer in women (representing $9.2 \%$ of the total) and men (representing $10.0 \%$ of the total) worldwide, respectively (27). The CRC cell lines which resist to TRAIL-induced apoptosis remains a problem in the treatment of these cancers, thus the approaches for enhancing TRAIL-induced apoptosis are urgently required. The LoVo cell line was used as a model of TRAIL-refractory colorectal cancer cells in this study as they were reported to express significantly lower level of cell surface DR5 than the other colon cancer cell lines resulting in resistance to TRAIL treatment (8). Thus, finding the strategy to overcome the TRAIL-insensitive cancer cells is of importance.

Goniothalamin is a major bioactive styryl-lactone compound found in plant Goniothalamus macrophyllus (Blume) Hook. f. \& Thomson, indigenous to South East Asia (28). Many reports suggested that goniothalamin showed cytotoxic activity against various cancer cell lines, such as liver, breast, and cervix (29-34). Interestingly, our preliminary studies indicated that goniothalamin could increase DR5 expression while decrease cFILP expression in LoVo cells. These preliminary results suggested that goniothalamin has a potential use for combination with TRAIL treatment in TRAIL-resistant LoVo cells. In this study, the mechanisms to overcome the resistance to TRAIL-induced apoptosis were investigated using goniothalamin combining with TRAIL in TRAIL-resistant LoVo cells. This indicated the potential application of goniothalamin as a synergistic agent for combining with TRAIL treatment in colorectal cancer.

\section{Materials and methods}

Chemical and antibodies. Goniothalamin (IUPAC name: (2R)-2-[(E)-2-phenylethenyl]-2,3-dihydropyran-6-one) was obtained from Dr Wilawan Mahabusarakam, Faculty of Science, Prince of Songkla University, Thailand in purified powder form. The stems of Goniothalamus macrophyllus were collected from Songkhla province in the southern part of Thailand, in September, 2007. Identification was made by Mr. Ponlawat Pattarakulpisutti, Department of Biology, Faculty of Science, Prince of Songkla University. The specimen (Uraiwan 01) has been deposited in the Herbarium of Department of Biology, Faculty of Science, Prince of Songkla University, Thailand. Recombinant TRAIL was purchased from Merck Millipore Corp. (Merck KGaA, Darmstadt, Germany). Chemicals for cell viability assay including MTT (3-(4,5-dimethyl)-2,5-diphenyl tetrazolium bromide) and dimethylsulfoxide (DMSO) were purchased from SigmaAldrich Corp. (St. Louis, MO, USA). Chemicals for flow cytometry analysis including Guava Cell Cycle ${ }^{\circledR}$ reagent and Guava Nexin ${ }^{\circledR}$ reagent were purchased from Merck Millipore Corp. (Merck KGaA), and PE-conjugated DR5 antibody was purchased from eBioscience, Inc. (San Diego, CA, USA). Chemical for fluorescence microscope observation Hoechst 33342 dye was purchased from Fisher Scientific, Inc. (Invitrogen $^{\mathrm{TM}}$, Waltham, MA, USA). Chemical for mRNA extraction and cDNA synthesis were purchased from Qiagen N.V. (QIAzol ${ }^{\mathrm{TM}}$ lysis reagent, Venlo, LI, The Netherlands) and Thermo Fisher Scientific, Inc. (RevertAid ${ }^{\mathrm{TM}}$ First Strand cDNA Synthesis kit, Fermentas ${ }^{\mathrm{TM}}$, Waltham, MA, USA), respectively. Chemical for quantitative PCR was obtained from Thermo Fisher Scientific, Inc. $\left(\mathrm{SYBR}^{\circledR}\right.$ Select Master Mix, Applied Biosystems ${ }^{\mathrm{TM}}$, Waltham, MA, USA). Antibodies (Abs) for immunoblot analysis including mouse monoclonal Abs against CHOP, and rabbit monoclonal Abs against DR5, PARP, caspase-3, caspase-8, caspase-9, Bcl2, Bax, Bid, Mcl1, and anti-mouse immunoglobulin $\mathrm{G}$ and anti-rabbit immunoglobulin $\mathrm{G}$ horseradish peroxidase-conjugated secondary antibodies were obtained from Cell Signaling Technology, Inc. (Danvers, MA, USA), and mouse monoclonal Abs against phospho-histone H2AX at Ser139 ( $\gamma$-H2AX), $\beta$-actin and rabbit monoclonal Abs against cFLIP were obtained from Merck Millipore Corp. (Merck KGaA).

Cell culture. Human colorectal cancer, LoVo cell line, was obtained from the American Type Culture Collection (ATCC, Manassas, VA, USA). It was maintained in RPMI-1640 medium (Gibco Life Technologies, Carlbad, CA, USA) supplemented with $10 \%$ fetal bovine serum (GE Healthcare Life Science, Little Chalfont, UK), $100 \mathrm{U} / \mathrm{ml}$ penicillin and $100 \mu \mathrm{g} / \mathrm{ml}$ streptomycin (GE Healthcare Life Science, Inc., Little Chalfont, $\mathrm{UK})$ at $37^{\circ} \mathrm{C}$ in a humidified $5 \% \mathrm{CO}_{2}$ atmosphere and used for assays during exponential phase of growth.

Cell viability assay. Cells/well $\left(5 \times 10^{3}\right)$ were seeded in a 96-well plate. After adherence, culture medium containing 10 and $100 \mathrm{ng} / \mathrm{ml}$ of TRAIL alone and in combination with different goniothalamin concentrations 5, 15, 25 and $50 \mu \mathrm{M}$ were incubated for $24 \mathrm{~h}$ at $37^{\circ} \mathrm{C}$ with $5 \% \mathrm{CO}_{2}$. The control group was treated with $0.5 \%$ DMSO. Cytotoxicity of gonio- 
thalamin was determined by cell proliferation analysis using MTT assay as described by Denizot and Lang (35). Briefly, after the indicated treatment, $0.5 \mathrm{mg} / \mathrm{ml}$ of MTT solution dissolved in culture medium was added and the cells were incubated for $2 \mathrm{~h}$ at $37^{\circ} \mathrm{C}$ with $5 \% \mathrm{CO}_{2}$ in the incubator, the MTT solution was removed and $100 \mu \mathrm{l}$ of DMSO was added to dissolve the formazan crystals, a product of cell respiration as for viable cells, and the absorbance at $540 \mathrm{~nm}$ was quantified on Epoch ${ }^{\mathrm{TM}}$ Microplate Spectrophotometer and analyzed by Gen5 ${ }^{\text {TM }}$ Data Analysis software (BioTek, CA, USA).

Chromatin condensation. Cells/well $\left(8 \times 10^{4}\right)$ were seeded in a 12-well plate. After adherence, culture medium containing 10 and $100 \mathrm{ng} / \mathrm{ml}$ of TRAIL alone and in combination with $15 \mu \mathrm{M}$ goniothalamin were incubated for $24 \mathrm{~h}$ at $37^{\circ} \mathrm{C}$ with $5 \% \mathrm{CO}_{2}$. The control group was treated with $0.5 \%$ DMSO. Chromatin condensation, a character of apoptosis, was detected by cell staining with a fluorescent dye Hoechst 33342 modified from Oberhammer et al (36). After treatment, the treated cells were washed and fixed with fixative solution (4\% paraformaldehyde) for $15 \mathrm{~min}$ at room temperature. The fixed cells were washed and then stained with chromatin staining solution $(5 \mu \mathrm{g} / \mathrm{ml}$ of Hoechst 33342) for $15 \mathrm{~min}$. After staining, the stained cell were washed and then the plates were observed using a fluorescence microscope IX73 model (Olympus, Tokyo, Japan) with U-MWU2 mirror units for ultraviolet excitation.

Cell cycle determination. Cells/well $\left(2 \times 10^{5}\right)$ were seeded in each 6-well plate. After adherence, culture medium containing 10 and $100 \mathrm{ng} / \mathrm{ml}$ of TRAIL alone and in combination with $15 \mu \mathrm{M}$ goniothalamin were incubated for $24 \mathrm{~h}$ at $37^{\circ} \mathrm{C}$ with $5 \% \mathrm{CO}_{2}$. The control group was treated with $0.5 \%$ DMSO. After treatment, the whole cells were collected and stained according to the manufacturer's instructions (Guava Cell Cycle ${ }^{\circledR}$ reagent from Merck Millipore Corp.; Merck KGaA). The stained cells were then sorted and analyzed for DNA content by a Guava easyCyte $^{\mathrm{TM}}$ flow cytometer and GuavaSoft ${ }^{\mathrm{TM}}$ software (Merck Millipore Corp.; Merck KGaA), respectively.

Cell surface phosphatidyl-serine determination. Cells/well $\left(2 \times 10^{5}\right)$ were seeded in a 6 -well plate. After adherence, culture medium containing 10 and $100 \mathrm{ng} / \mathrm{ml}$ of TRAIL alone and in combination with $15 \mu \mathrm{M}$ goniothalamin were incubated for $24 \mathrm{~h}$ at $37^{\circ} \mathrm{C}$ with $5 \% \mathrm{CO}_{2}$. The control group was treated with $0.5 \%$ DMSO. After treatment, whole cells were collected and stained according to the manufacturer's instructions (Guava Nexin ${ }^{\circledR}$ reagent from Merck Millipore Corp.; Merck $\mathrm{KGaA}$ ). The stained cells were sorted and analyzed for cell surface phosphatidyl-serine content a Guava easyCyte ${ }^{\mathrm{TM}}$ flow cytometer and GuavaSoft ${ }^{\mathrm{TM}}$ software (Merck Millipore Corp.; Merck KGaA), respectively.

Cell surface DR5 determination. Cells/well $\left(2 \times 10^{5}\right)$ were seeded in a 6-well plate. After adherence, culture medium containing different goniothalamin concentrations of $1,5,15$ and $25 \mu \mathrm{M}$ was incubated for $24 \mathrm{~h}$ at $37^{\circ} \mathrm{C}$ with $5 \% \mathrm{CO}_{2}$. The control group was treated with $0.5 \%$ DMSO. After treatment, the whole cells were collected and resuspended in PBS buffer containing PE-conjugated DR5 antibody, then incubated in the dark for $1 \mathrm{~h}$ at room temperature. The cells were washed and resuspended in PBS solution then sorted and analyzed for cell surface DR5 by a Guava easyCyte ${ }^{\mathrm{TM}}$ flow cytometer and GuavaSoft software (Merck Millipore Corp.; Merck KGaA), respectively.

$m R N A$ expression analysis. Cells/well $\left(8 \times 10^{4}\right)$ were seeded in a 12 -well plate. After adherence, culture medium containing $15 \mu \mathrm{M}$ goniothalamin was incubated for $24 \mathrm{~h}$ at $37^{\circ} \mathrm{C}$ with $5 \% \mathrm{CO}_{2}$. The control group was treated with $0.5 \%$ DMSO. Analysis of mRNA expression was performed using the two step quantitative reverse transcriptase (RT)-PCR. After treatment, the whole cells were collected and RNA was extracted by using QIAzol lysis reagent (Qiagen N.V.) and cDNA synthesis by reverse transcription according RevertAid First Strand cDNA Synthesis kit (Fermentas, Thermo Fisher Scientific) with $2 \mu \mathrm{g}$ of total RNA of each sample. In quantitative PCR step, it was performed with SYBR Select Master Mix (Applied Biosystems, Thermo Fisher Scientific, Inc., Waltham, MA, USA). The primers used for amplification were: DR5 (forward 5'-CACCAGGTGTGATTCAGGTG-3' and reverse 5'-TACGGCTGCAACTGTGACTC-3'), CHOP (forward 5'-GCGCATGAAGGAGAAAGAAC-3' and reverse 5'-TCACC

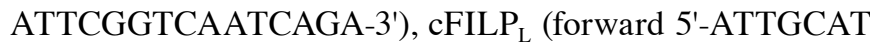
TGGCAATGAGACAGAGC-3' and reverse 5'-TCGGTGCT

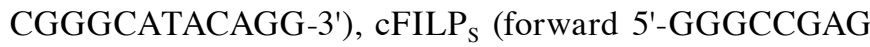
GCAAGATAAGCAAGG-3' and reverse 5'-TCAGGACAAT GGGCATAGGGTGT-3'), and GAPDH (forward 5'-AGGTCG GAGTCAACGGATTT-3' and reverse 5'-TAGTTGAGGTC AATGAAGGG-3'). The PCR amplification was analyzed by CFX96 Touch $^{\text {TM }}$ Real-Time PCR Detection system with CFX Manager $^{\mathrm{TM}}$ software (Bio-Rad Laboratories, Inc., CA, USA). All steps were performed according to the manufacturer's instructions.

Protein expression analysis by immunoblotting. Cells/well $\left(2 \times 10^{5}\right)$ were seeded in a 6 -well plate. After adherence, the cells were treated with appropriate condition. After treatment, the cells were lysed with RIPA lysis buffer $(50 \mathrm{mM}$ Tris- $\mathrm{HCl}$, $\mathrm{pH} 7.4,1 \% \mathrm{NP}-40,0.5 \% \mathrm{C}_{24} \mathrm{H}_{39} \mathrm{NaO}_{4}, 0.1 \%$ SDS, $150 \mathrm{mM}$ $\mathrm{NaCl}, 2 \mathrm{mM}$ EDTA, $50 \mathrm{mM} \mathrm{NaF}$ ). The extracted proteins were separated on $8-15 \%$ acrylamind gel and transferred onto a polyvinylidene fluoride (PVDF) membrane (Merck Millipore Corp., Merck KGaA). Then, the membranes were blocked with $5 \%$ skimmed-milk in TBS-Tween buffer for $1 \mathrm{~h}$ at room temperature and incubated with mouse monoclonal Abs against CHOP, $\gamma-\mathrm{H} 2 \mathrm{AX}$, and rabbit monoclonal Abs against DR5, PARP, caspase-3, caspase-8, caspase-9, $\mathrm{Bcl} 2$, Bax, Bid), cFLIP, $\beta$-actin overnight at $4^{\circ} \mathrm{C}$. Following incubation with anti-mouse immunoglobulin $\mathrm{G}$ or anti-rabbit immunoglobulin $\mathrm{G}$ horseradish peroxidase-conjugated secondary antibodies for $1 \mathrm{~h}$ a room temperature, the signals were developed using Immobilon ${ }^{\mathrm{TM}}$ Western chemiluminescent HRP substrate (Merck Millipore Corp., Merck KGaA, Darmstadt, Germany) and detected under Chemiluminescent Imaging system (GeneGnome gel documentation, Synoptics Ltd., Cambridge, UK).

Statistical analysis. To compare the data from different treatments, Student's t-test was used. All data presented 


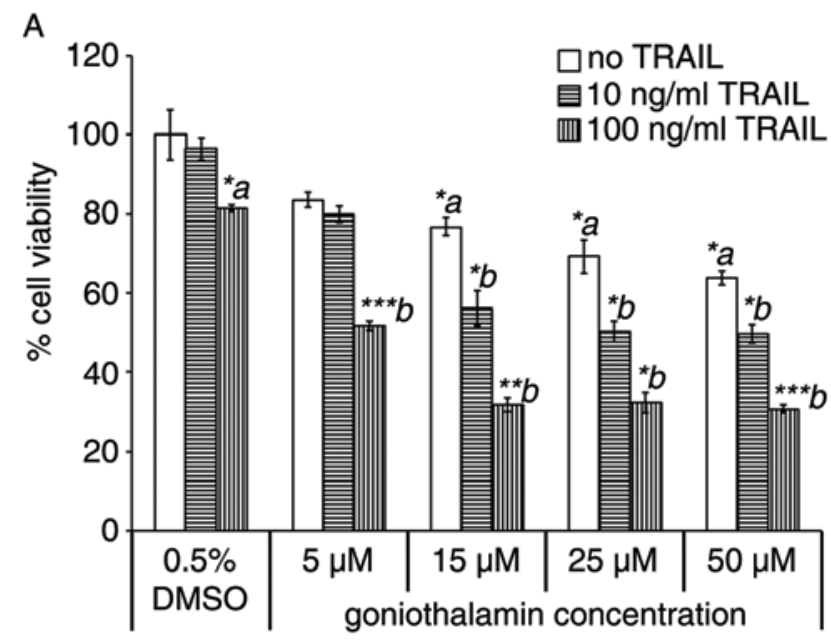

B
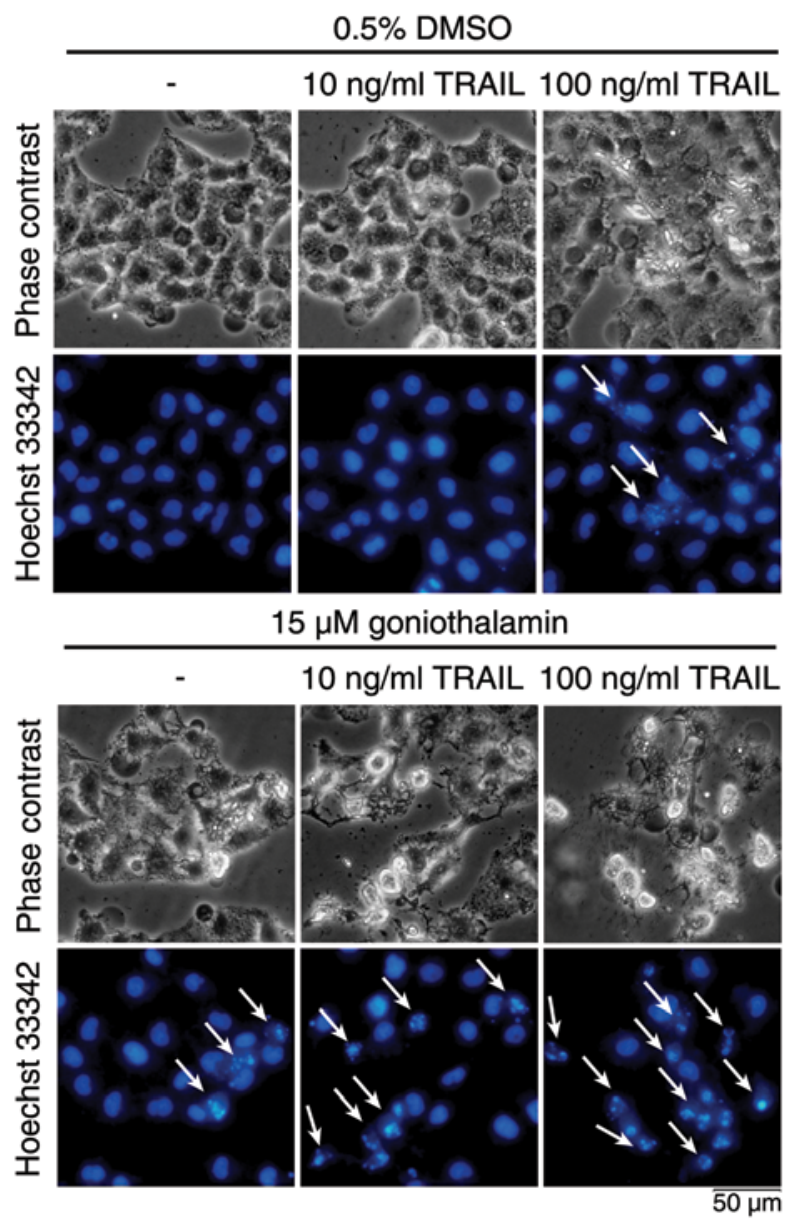

Figure 1. Effects of combined treatment of TRAIL and goniothalamin on cell viability and chromatin condensation. (A) LoVo cell were treated with various concentrations of goniothalamin combined with or without TRAIL for $24 \mathrm{~h}$ and then \% cell viability was determined by MTT assay. (B) Chromatin condensation was observed by Hoechst 33342 staining (indicated by white arrow) upon the combined treatment of $15 \mu \mathrm{M}$ goniothalamin with or without TRAIL for $24 \mathrm{~h}$. Significant values were defined as ${ }^{*} \mathrm{p}<0.05$, ${ }^{* *} \mathrm{p}<0.01$ and ${ }^{* * *} \mathrm{p}<0.001$; a, defined as compared with $0.5 \%$ DMSO treatment alone as a control; and b, defined as compared with no TRAIL treatment in each concentration of goniothalamin treatment.

were obtained from at least three independent experiments and presented as mean \pm standard deviation $(\mathrm{SD})$. A p-value of 0.05 was taken as minimum basis for assigning significance.

\section{Results}

Enhanced TRAIL-induced apoptosis in LoVo cells by co-treatment with goniothalamin. Our preliminary study showed that LoVo cells were insensitive to goniothalamin treatment with high $\mathrm{IC}_{50}$ value at $65.25 \pm 1.85 \mu \mathrm{M}$. However, goniothalamin induced increased DR5 expression at lower concentration than $\mathrm{IC}_{50}$ value indicating that goniothalamin in combination with TRAIL may have a potential to trigger apoptosis induction via the death receptor-TRAIL mediated apoptosis pathway. Thus, we tried to investigate the mechanisms of apoptosis induction upon combination of TRAIL and goniothalamin in LoVo cells.

In this study, we first found that co-treatment of goniothalamin and TRAIL enhanced cytotoxicity induction in LoVo cells. We confirmed this cytotoxic effects and apoptosis induction using the MTT assay and Hoechst 33342 staining to assess chromatin condensation as shown in Fig. 1A and B, respectively. Treatment of LoVo cells with 10 and $100 \mathrm{ng} / \mathrm{ml}$ of TRAIL for $24 \mathrm{~h}$ showed $>80 \%$ cell viability, while combined treatment with $15 \mu \mathrm{M}$ goniothalamin resulted in enhanced cytotoxicity in LoVo cells. The increased chromatin condensation is shown in Fig. 1B upon combining treatment of $15 \mu \mathrm{M}$ goniothalamin and 10 and $100 \mathrm{ng} / \mathrm{ml}$ of TRAIL as compared to a single treatment. Moreover, other apoptotic characteristics, accumulation of subG1 phase population and cell surface phosphatidyl-serine presentation, were studied using flow cytometry technique. As shown in Fig. 2A and C, a significant increased accumulation of a subG1 phase population was detected upon treatment with $15 \mu \mathrm{M}$ goniothalamin and $10 \mathrm{ng} / \mathrm{ml}$ TRAIL as compared to a single treatment, but not for the combination of $15 \mu \mathrm{M}$ goniothalamin and $100 \mathrm{ng} / \mathrm{ml}$ TRAIL as compared to a single $100 \mathrm{ng} / \mathrm{ml}$ TRAIL treatment. In addition, the significant increased cell surface phosphatidyl-serine presentation was detected upon combined treatment with both 10 and $100 \mathrm{ng} / \mathrm{ml}$ of TRAIL as compared to a single treatment (Fig. 2B and D). Thus, these results indicated that the combined treatment of goniothalamin and TRAIL enhanced cytotoxicity and apoptosis induction in LoVo cells, especially at $15 \mu \mathrm{M}$ goniothalamin and $10 \mathrm{ng} / \mathrm{ml}$ TRAIL, which was selected for use in the next steps to assess apoptosis pathway.

Combined treatment with goniothalamin and TRAIL accelerate apoptosis induction by a caspase activationdependent pathway involved with both death receptor-and mitochondrial-mediated apoptosis pathways in LoVo cells. To observe whether the combination of goniothalamin and TRAIL leads to activation of caspase-activated apoptosis in TRAIL-resistant LoVo cells, apoptotic-related protein was assessed by immunoblot analysis. As shown in Fig. 3, caspaseactivated apoptotic mediators including PARP and caspase- 3 as executive apoptosis, caspase- 8 and $\mathrm{Bid}$ as death receptor mediated apoptosis pathway, caspase-9, Bcl2 and Bax as mitochondrial mediated apoptosis pathway were determined. The results indicated that both extrinsic and intrinsic pathway were enhanced upon combined treatment of $15 \mu \mathrm{M}$ goniothalamin and 10 or $100 \mathrm{ng} / \mathrm{ml}$ of TRAIL, as confirmed by increasing the cleaved form of PARP, caspase-3, caspase-8, caspase-9, Bid, decreased antiapoptotic $\mathrm{Bcl} 2$ and increased proapoptotic Bax expression. Moreover, increased phosphorylation of histone 
A

no TRAIL

$0 \mathrm{ng} / \mathrm{ml}$ TRAIL
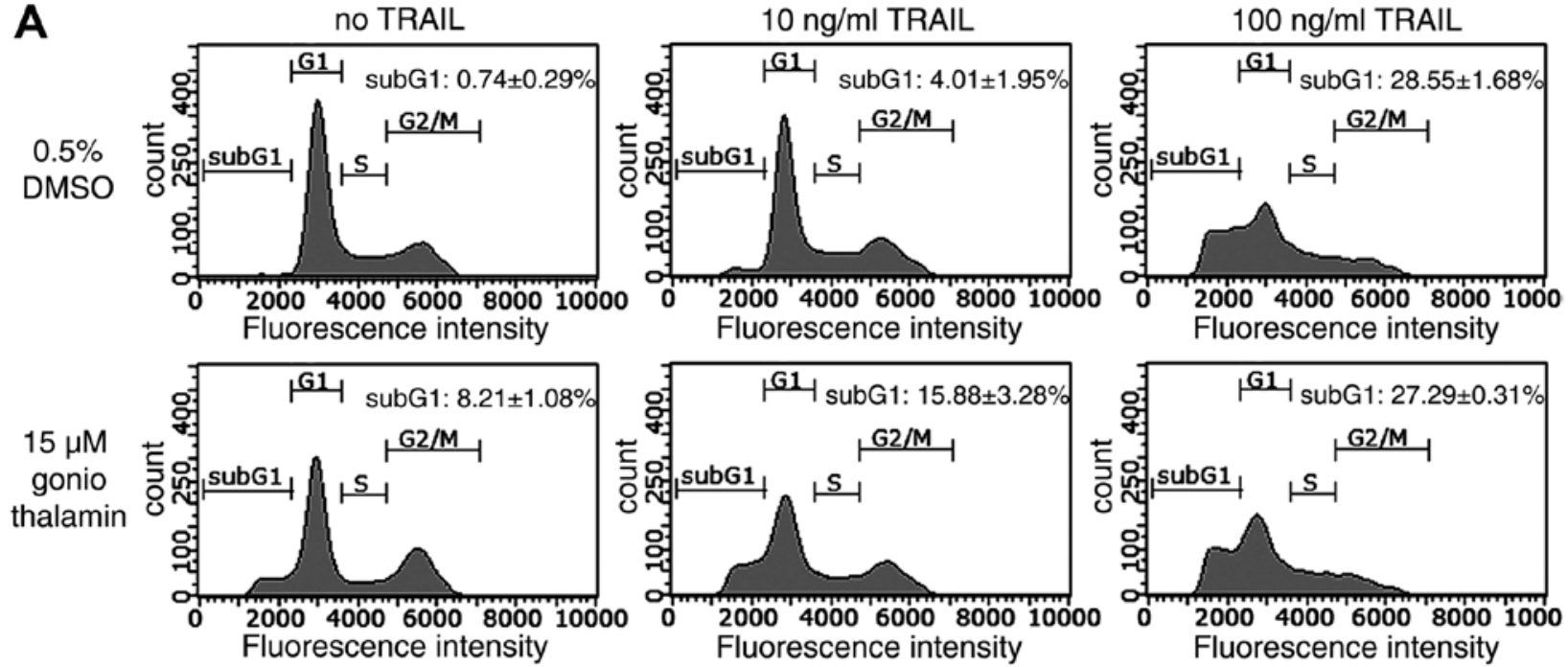

B
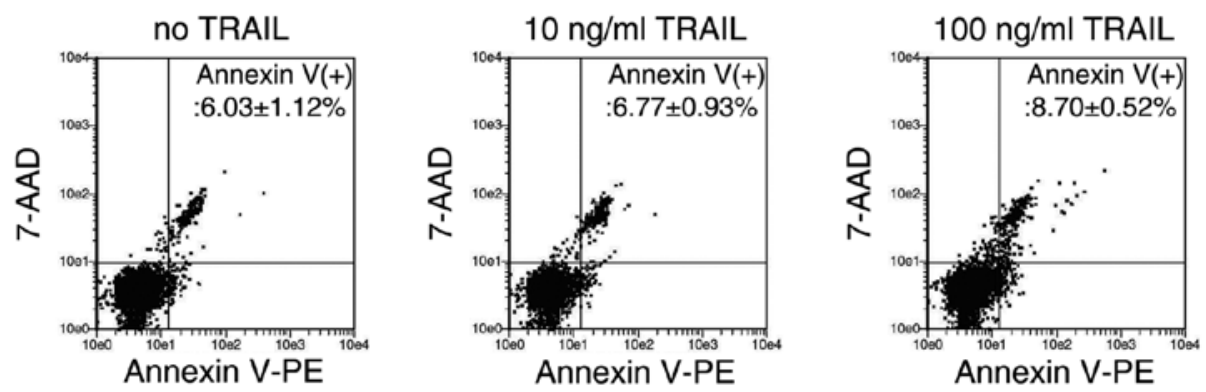

$0.5 \%$ DMSO

$15 \mu \mathrm{M}$ goniothalamin
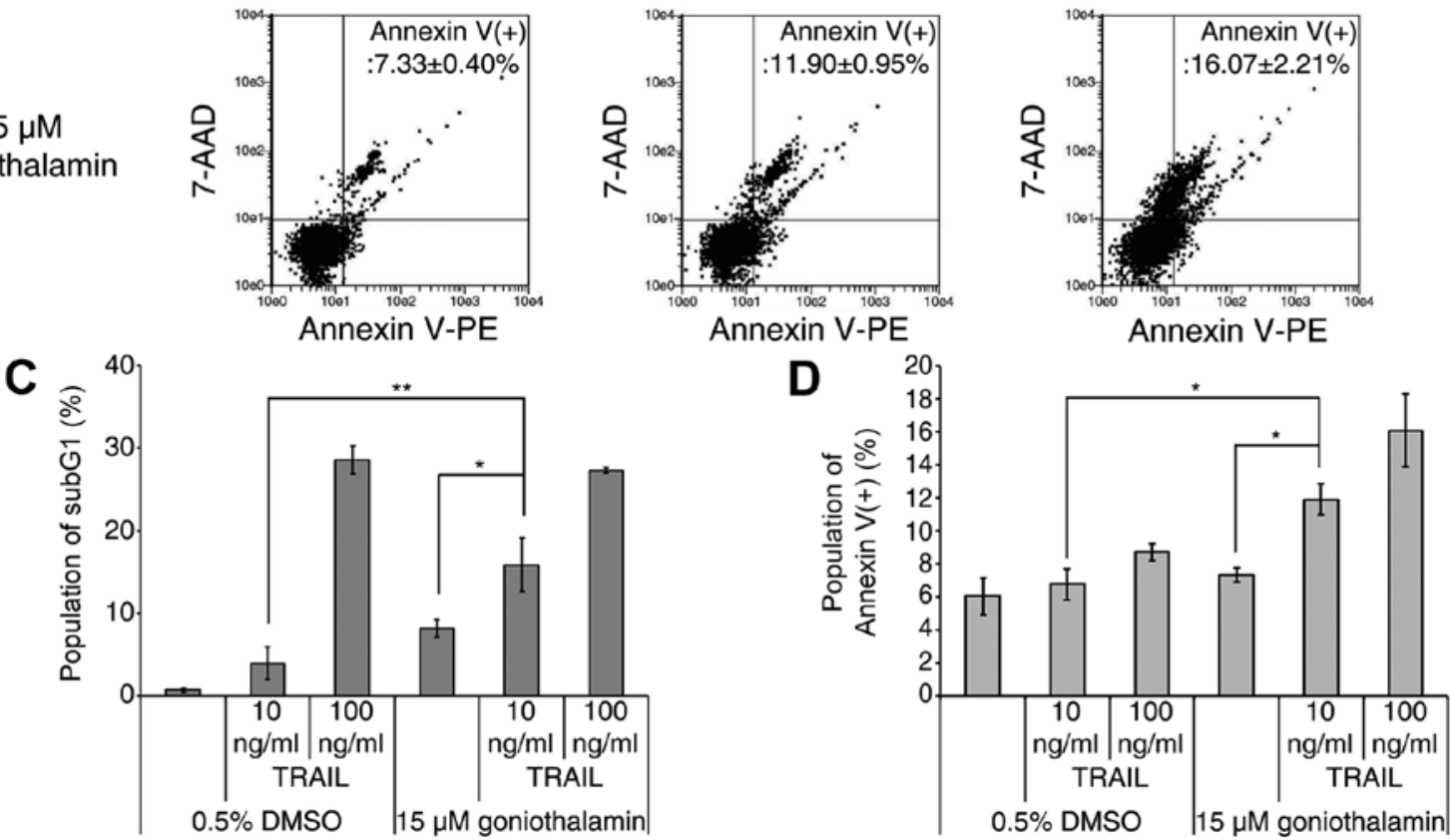

Figure 2. Combined treatment of TRAIL and goniothalamin induced apoptosis in LoVo cells. LoVo cells were treated with $15 \mu \mathrm{M}$ goniothalamin combined with or without TRAIL for $24 \mathrm{~h}$ and then stained with: (A) Guava Cell Cycle reagent for cell cycle analysis and (B) Guava Nexin reagent for determination of cell surface phosphatidyl-serine presentation. Sorting cells and analyzed by a Guava easyCyte flow cytometer and GuavaSoft software (Merck Millipore), respectively. The bar graphs represent (C) the number of cells in subG1 phase and (D) number of Annexin V-positive cell population indicating phosphatidylserine exposure. Significant values were defined as ${ }^{*} \mathrm{p}<0.05$ and ${ }^{* *} \mathrm{p}<0.01$.

the so-called $\gamma$-H2AX, was observed upon the combined treatments, these results indicated that goniothalamin induced DNA double-strand breaks and triggered apoptosisassociated $\gamma-\mathrm{H} 2 \mathrm{AX}$ accumulation, which is one of apoptotic characteristics. The results indicated that these combined treatment can induce cytotoxicity resulting in DNA doublestrand break in LoVo cells.

Goniothalamin enhances TRAIL-induced apoptosis through DR5 upregulation and cFLIP downregulation. 


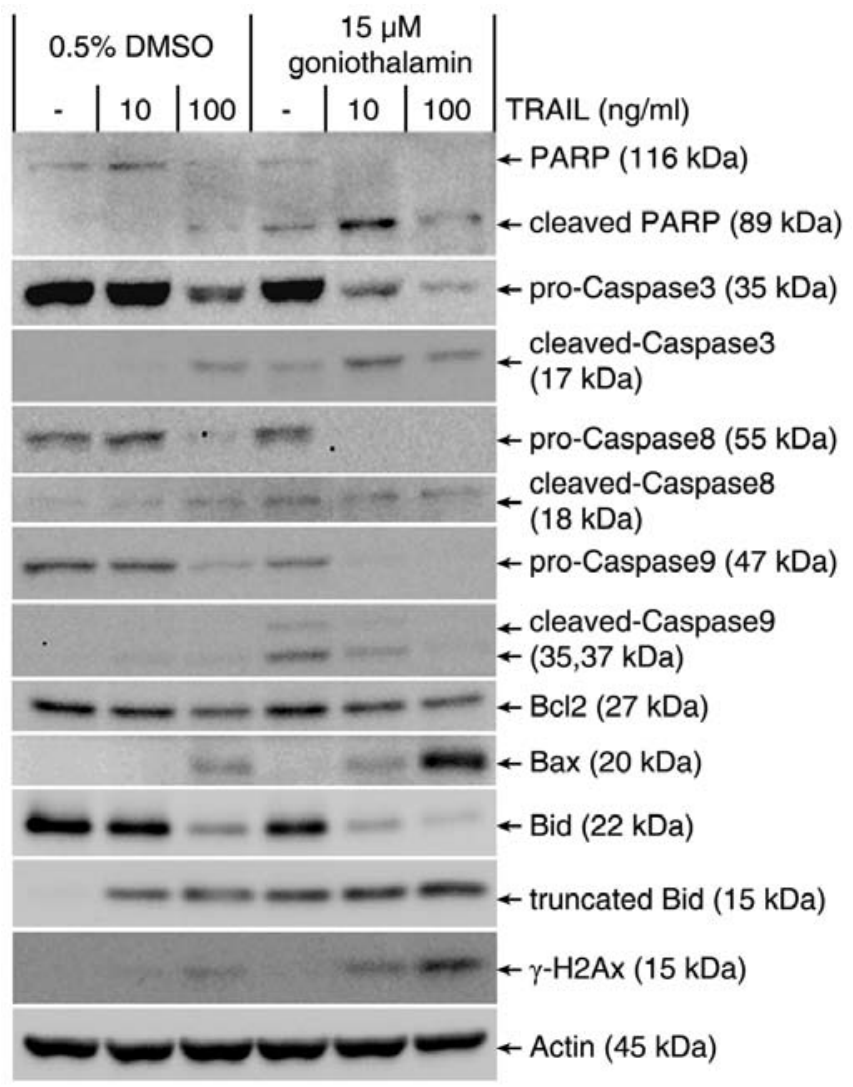

Figure 3. Effects of combined treatment of TRAIL and goniothalamin on induction of apoptotic related proteins. LoVo cells were treated with $15 \mu \mathrm{M}$ goniothalamin combined with or without TRAIL for $24 \mathrm{~h}$ and then the whole protein lysate was separated on SDS-PAGE followed by immunoblot analysis, actin was used as loading control.

TRAIL-stimulated death signal is initiated by the binding of TRAIL to DR5 resulted in the subsequent caspase- 8 activation. As shown in Fig. 4, immunoblot analysis showed that goniothalamin dramatically upregulated the DR5 and CHOP protein but downregulated the cFLIP and Mcl1 protein in a dose-dependent manner (Fig. 4A). Treatment with $15 \mu \mathrm{M}$ goniothalamin at various time points showed that goniothalamin upregulated the DR5 and CHOP protein while downregulated the antiapoptotic cFLIP and Mcl1 in a timedependent manner (Fig. 4B). These results corresponded with quantitative RT-PCR analysis (Fig. 4C) indicating that DR5 and $\mathrm{CHOP}$ mRNA were upregulated whereas $\mathrm{CFLIP}_{\mathrm{L}}$ and cFLIP $_{\mathrm{S}}$ mRNA was significantly downregulated. Moreover, the translocation of DR5 to cell surface was analyzed and the results indicated that goniothalamin increased cell surface DR5 expression in a dose-dependent manner (Fig. 4D). These results implied that DR5 upregulation induced by increased CHOP expression together with the downregulation of cFLIP and Mcll contributed to enhanced TRAIL sensitization.

\section{Discussion}

TRAIL, also known as Apo-2L, is a typical member of TNF ligand family that induces apoptosis via death-receptor mediated pathway. TRAIL has potential benefits in cancer therapy because of its potent ability to be selectively toxic in cancer cells. Unlike the other death ligands such as TNF- $\alpha$ or FasL, the treatment of TRAIL causes less toxic in normal cells $(37,38)$. Furthermore, the combined treatment of TRAIL and genotoxic chemotherapeutic agents synergistically inhibited cancer cell growth which are otherwise resistant or less toxicity to treatment with TRAIL or chemotherapy alone (37-39). There are several recombinant TRAIL and TRAIL-receptor agonists as an anticancer therapy that have been tested in phase I and II trials in patients with advanced cancer. Clinical studies in TRAIL-receptor agonist are being investigated using combination treatment in patients with advanced cancer stage (40). However, the single TRAIL treatment probably is not feasible since the majority of cancer cells are resistant to TRAIL. Thus, the combination treatment with TRAIL and chemotherapy is essential for use in TRAIL-resistant cancers. We also analyzed in detail that TRAIL combined treatment with cytotoxic agent goniothalamin may enhance cytotoxicity and apoptosis induction in colorectal cancer cells, indicating a potential use for cancer therapy.

In this study, we demonstrated for the first time that goniothalamin upon combined treatment with TRAIL-regulated expression of antiapoptotic- and proapoptotic-related death receptor-mediated apoptotic molecules, including upregulation of DR5 and CHOP, downregulation of cFLIP and Mcl1 resulting in enhancement of the ability of TRAIL in TRAIL refractory LoVo cells. Various studies have reported the increased transcriptional activation of DR5 gene by the upregulation of CHOP expression (41-45), these correlated to the upregulation of CHOP expression in goniothalamin treatment. Another mechanism which is involved in sensitization to TRAIL-induced apoptosis is downregulation of cFLIP and Mcl1. cFLIP is the major protein that prevents caspase- 8 from activation by death receptors through binding to FADD and/or caspase- 8 and TRAIL receptor DR5 in a ligand-dependent and -independent manner and forms an apoptosis inhibitory complex (AIC), then prevents death-inducing signaling complex (DISC) formation and subsequently suppress the activation of caspase cascade (46-53). Mcl1 is an antiapoptotic protein involved in death receptor mediated pathway crosslink to mitochondrial mediated pathway by interacting with truncated Bid (tBid) and then strongly inhibits tBid-induced cytochrome $c$ release in mitochondrial mediated apoptosis pathway (54-57). Downregulation of cFLIP and Mcl1 expression sensitizes TRAIL-induced apoptosis in various TRAIL refractory cancers. Thus, we speculated that goniothalamin plus TRAIL might play a critical role in goniothalaminstimulated TRAIL-mediated apoptosis in LoVo cells through both upregulation of DR5 and CHOP and downregulation of cFLIP and Mcl1 expression enhancing TRAIL ability to be selectively cytotoxic to TRAIL-refractory LoVo cells. Moreover, DR5 translocation to cell surface was increased by goniothalamin treatment that may increase potent death receptor-mediated apoptosis induction by TRAIL through binding to DR5 (58-60).

Caspase-dependent pathways of these TRAIL-mediated apoptosis are involved in this combination treatment, resulting in a strong enhancement of PARP, caspase-3, -8 and -9 activation. TRAIL triggered death receptor mediated apoptosis pathway via binding to death receptor DR5 resulting in induction cleavage of $\mathrm{Bid}$ to $\mathrm{tBid}$, then crosslinking to 

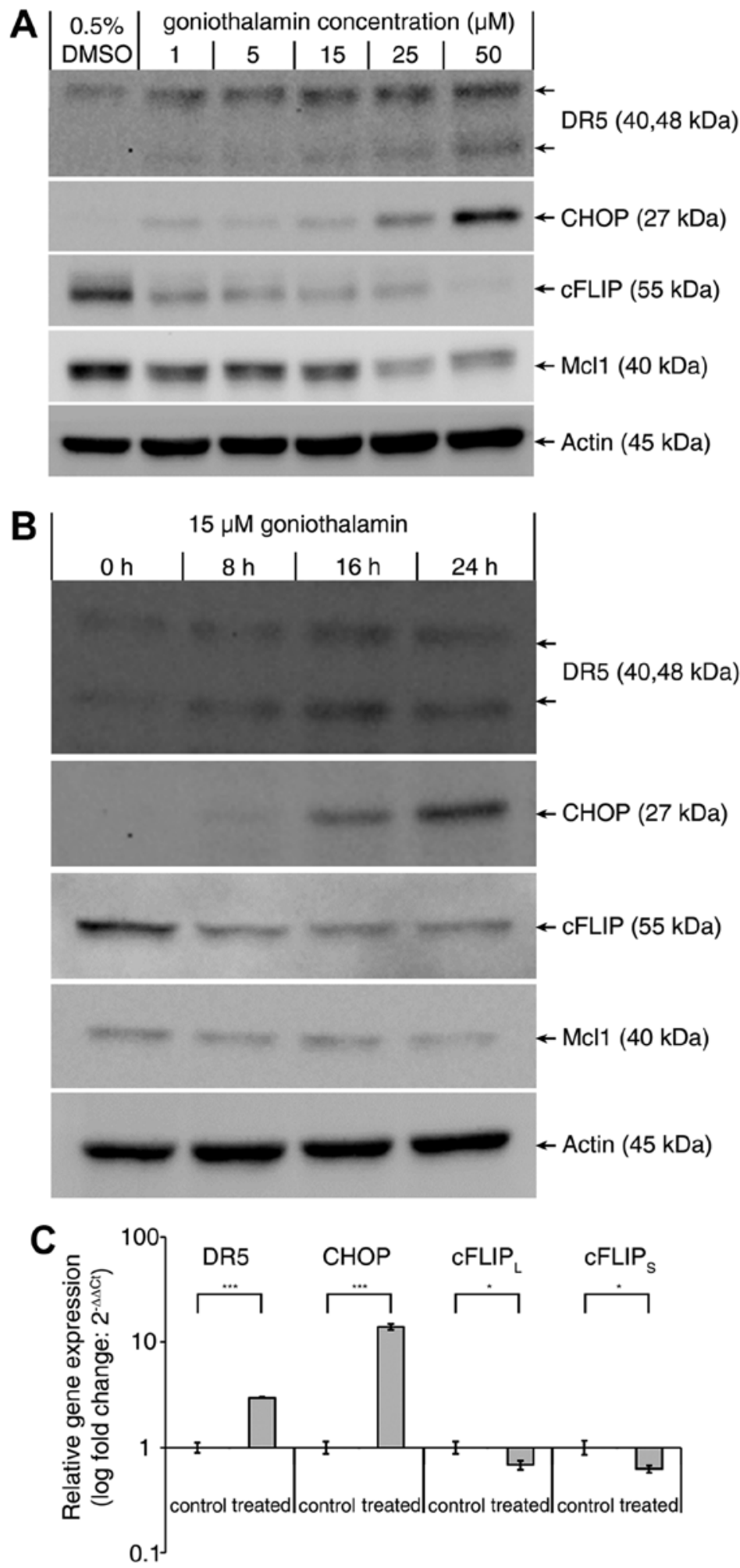
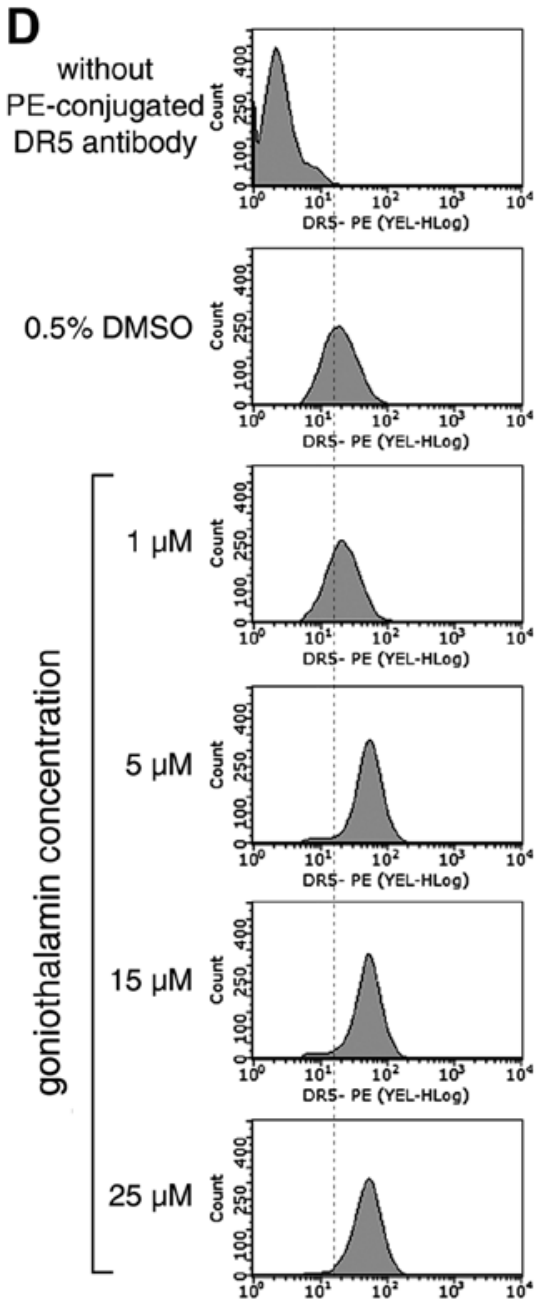

fluorescence intensity

Figure 4. Effects of goniothalamin on induction of death receptor mediated apoptosis pathway associated with TRAIL-induced apoptosis. (A) LoVo cells were treated with various concentrations of goniothalamin for $24 \mathrm{~h}$ or (B) LoVo cells were treated with $15 \mu \mathrm{M}$ goniothalamin for various time of treatment and the whole protein lysate was separated on SDS-PAGE followed by immunoblot analysis, actin was used as loading control. (C) Expression of apoptosis mRNA genes were determined by reverse transcription quantitative PCR. Significant values were defined as * $\mathrm{p}<0.05$, and ${ }^{* * *} \mathrm{p}<0.001$, compared with $0.5 \%$ DMSO treatment as a control in each gene. (D) Goniothalamin increased cell surface DR5 presentation in LoVo cells upon treatment with various goniothalamin concentrations for $24 \mathrm{~h}$. The cells were stained with PE-conjugated antibodies against DR5 and detected with a flow cytometer.

mitochondria-mediated apoptosis activation (4-7,61), supported by downregulation of Mcl1 in goniothalamin treatment. Our results showed that apoptotic related molecules triggered activation in both death receptor- and mitochondrial-mediated apoptosis pathways under combination treatment of goniothalamin and TRAIL. Moreover, the increased accumulation 
of subG1 phase population in cell cycle, increased cell surface phosphatidyl-serine presentation and increased phosphorylation of $\mathrm{H} 2 \mathrm{AX}$ were observed under the combined treatment of TRAIL and goniothalamin, indicating apoptosis induction in LoVo cells as compared to a single treatment with TRAIL or goniothalmin alone (62-65). Similar reports of other compounds sensitize TRAIL-induced apoptosis include inostamycin (19), delphinidin (66), and parthenolide (67). Therefore, the combined treatment of TRAIL and goniothalamin enhanced cytotoxicity in TRAIL refractory LoVo cells through caspase-dependent apoptosis pathway in both death receptor- and mitochondrial-mediated pathways.

In conclusion, this is the first report that the combination of TRAIL and goniothalamin was able to effectively enhance TRAIL mediated apoptosis induction in TRAIL refractory colorectal cancer, LoVo cells. In addition, we found that goniothalamin enhanced TRAIL sensitization in LoVo cells associated with caspase cascade activation via induction of the DR5 pathway and decreased expression level of antiapoptotic proteins which related to DR5 pathway and subsequently increased apoptosis. From these results, we speculate that combined treatment of TRAIL and goniothalamin provides a possible therapeutic application for treatment of colorectal cancer that are resistant to TRAIL.

\section{Acknowledgements}

This study was supported by The Royal Golden Jubilee (RGJ) Ph.D. Program from Thailand Research Fund (TRF) Thailand and the Strategic Wisdom and Research Institute, Srinakharinwirot University, Bangkok, Thailand.

\section{References}

1. Fukuda M, Hamao A, Tanaka A, Kitada M, Suzuki S, Kusama K and Sakashita H: Tumor necrosis factor-related apoptosisinducing ligand (TRAIL/APO2L) and its receptors expression in human squamous cell carcinoma of the oral cavity. Oncol Rep 10: 1113-1119, 2003

2. Kichev A, Rousset CI, Baburamani AA, Levison SW, Wood TL, Gressens P, Thornton C and Hagberg H: Tumor necrosis factorrelated apoptosis-inducing ligand (TRAIL) signaling and cell death in the immature central nervous system after hypoxiaischemia and inflammation. J Biol Chem 289: 9430-9439, 2014.

3. Walczak H, Miller RE, Ariail K, Gliniak B, Griffith TS, Kubin M, Chin W, Jones J, Woodward A, Le T, et al: Tumoricidal activity of tumor necrosis factor-related apoptosis-inducing ligand in vivo. Nat Med 5: 157-163, 1999.

4. Li H, Zhu H, Xu CJ and Yuan J: Cleavage of BID by caspase 8 mediates the mitochondrial damage in the Fas pathway of apoptosis. Cell 94: 491-501, 1998.

5. Gross A, McDonnell JM and Korsmeyer SJ: BCL-2 family members and the mitochondria in apoptosis. Genes Dev 13 1899-1911, 1999.

6. Schug ZT, Gonzalvez F, Houtkooper RH, Vaz FM and Gottlieb E: BID is cleaved by caspase- 8 within a native complex on the mitochondrial membrane. Cell Death Differ 18: 538-548, 2011.

7. Kantari $\mathrm{C}$ and Walczak H: Caspase- 8 and bid: Caught in the act between death receptors and mitochondria. Biochim Biophys Acta 1813: 558-563, 2011.

8. Galligan L, Longley DB, McEwan M, Wilson TR, McLaughlin K and Johnston PG: Chemotherapy and TRAIL-mediated colon cancer cell death: The roles of p53, TRAIL receptors, and c-FLIP. Mol Cancer Ther 4: 2026-2036, 2005.

9. Zhang L and Fang B: Mechanisms of resistance to TRAILinduced apoptosis in cancer. Cancer Gene Ther 12: 228-237, 2005.
10. Lemke J, von Karstedt S, Zinngrebe J and Walczak H: Getting TRAIL back on track for cancer therapy. Cell Death Differ 21: 1350-1364, 2014.

11. Grambihler A, Higuchi H, Bronk SF and Gores GJ: cFLIP-L inhibits p38 MAPK activation: An additional anti-apoptotic mechanism in bile acid-mediated apoptosis. J Biol Chem 278: 26831-26837, 2003.

12. Nagane M, Pan G, Weddle JJ, Dixit VM, Cavenee WK and Huang HJ: Increased death receptor 5 expression by chemotherapeutic agents in human gliomas causes synergistic cytotoxicity with tumor necrosis factor-related apoptosis-inducing ligand in vitro and in vivo. Cancer Res 60: 847-853, 2000.

13. Sheikh MS, Burns TF, Huang Y, Wu GS, Amundson S, Brooks KS, Fornace AJ Jr and el-Deiry WS: p53-dependent and -independent regulation of the death receptor KILLER/DR5 gene expression in response to genotoxic stress and tumor necrosis factor alpha. Cancer Res 58: 1593-1598, 1998.

14. Liu X, Yue P, Chen S, Hu L, Lonial S, Khuri FR and Sun SY: The proteasome inhibitor PS-341 (bortezomib) up-regulates DR5 expression leading to induction of apoptosis and enhancement of TRAIL-induced apoptosis despite up-regulation of c-FLIP and survivin expression in human NSCLC cells. Cancer Res 67: 4981-4988, 2007.

15. Shiraishi T, Yoshida T, Nakata S, Horinaka M, Wakada M, Mizutani Y, Miki T and Sakai T: Tunicamycin enhances tumor necrosis factor-related apoptosis-inducing ligand-induced apoptosis in human prostate cancer cells. Cancer Res 65: 6364-6370, 2005.

16. Lim JH, Park JW, Choi KS, Park YB and Kwon TK: Rottlerin induces apoptosis via death receptor 5 (DR5) upregulation through CHOP-dependent and PKC delta-independent mechanism in human malignant tumor cells. Carcinogenesis 30 : 729-736, 2009.

17. Kikuchi H, Ohtsuki T, Koyano T, Kowithayakorn T, Sakai T and Ishibashi M: Brandisianins A-F, isoflavonoids isolated from Millettia brandisiana in a screening program for death-receptor expression enhancement activity. J Nat Prod 70: 1910-1914, 2007.

18. Kim YH, Park JW, Lee JY and Kwon TK: Sodium butyrate sensitizes TRAIL-mediated apoptosis by induction of transcription from the DR5 gene promoter through Sp1 sites in colon cancer cells. Carcinogenesis 25: 1813-1820, 2004.

19. Yamamoto K, Makino M, Watanapokasin R, Tashiro E and Imoto M: Inostamycin enhanced TRAIL-induced apoptosis through DR5 upregulation on the cell surface. J Antibiot (Tokyo) 65: 295-300, 2012.

20. Zhou W, Cao A, Wang L and Wu D: Kurarinone synergizes TRAIL-induced apoptosis in gastric cancer cells. Cell Biochem Biophys 72: 241-249, 2014.

21. Han H, Xu B, Hou P, Jiang C, Liu L, Tang M, Yang X, Zhang Y and Liu Y: Icaritin sensitizes human glioblastoma cells to TRAIL-induced apoptosis. Cell Biochem Biophys 72: 533-542, 2015.

22. Henrich CJ, Brooks AD, Erickson KL, Thomas CL, Bokesch HR, Tewary P, Thompson CR, Pompei RJ, Gustafson KR, McMahon JB and Sayers TJ: Withanolide E sensitizes renal carcinoma cells to TRAIL-induced apoptosis by increasing cFLIP degradation. Cell Death Dis 6: e1666, 2015.

23. Son YG, Kim EH, Kim JY, Kim SU, Kwon TK, Yoon AR, Yun CO and Choi KS: Silibinin sensitizes human glioma cells to TRAIL-mediated apoptosis via DR5 up-regulation and downregulation of c-FLIP and survivin. Cancer Res 67: 8274-8284, 2007.

24. Lee DH, Kim DW, Jung CH, Lee YJ and Park D: Gingerol sensitizes TRAIL-induced apoptotic cell death of glioblastoma cells. Toxicol Appl Pharmacol 279: 253-265, 2014.

25. Tse AK, Cao HH, Cheng CY, Kwan HY, Yu H, Fong WF and Yu ZL: Indomethacin sensitizes TRAIL-resistant melanoma cells to TRAIL-induced apoptosis through ROS-mediated upregulation of death receptor 5 and downregulation of survivin. J Invest Dermatol 134: 1397-1407, 2014.

26. Ahmed D, Eide PW, Eilertsen IA, Danielsen SA, Eknæs M, Hektoen M, Lind GE and Lothe RA: Epigenetic and genetic features of 24 colon cancer cell lines. Oncogenesis 2: e71, 2013.

27. Ferlay J, Soerjomataram I, Dikshit R, Eser S, Mathers C, Rebelo M, Parkin DM, Forman D and Bray F: Cancer incidence and mortality worldwide: Sources, methods and major patterns in GLOBOCAN 2012. Int J Cancer 136: E359-E386, 2015. 
28. Wattanapiromsakul C, Wangsintaweekul B, Sangprapan P, Itharat $\mathrm{A}$ and Keawpradub N: Goniothalamin, a cytotoxic compound, isolated from Goniothalamus macrophyllus (Blume) Hook. f. \&Thomson var. macrophyllus. Songklanakarin J Sci Technol 27: 479-487, 2005.

29. Inayat-Hussain SH, Annuar BO, Din LB, Ali AM and Ross D: Loss of mitochondrial transmembrane potential and caspase- 9 activation during apoptosis induced by the novel styryl-lactone goniothalamin in HL-60 leukemia cells. Toxicol In Vitro 17: 433-439, 2003

30. Chan KM, Rajab NF, Ishak MH, Ali AM, Yusoff K, Din LB and Inayat-Hussain SH: Goniothalamin induces apoptosis in vascular smooth muscle cells. Chem Biol Interact 159: 129-140, 2006.

31. Chen WY, Wu CC, Lan YH, Chang FR, Teng CM and Wu YC: Goniothalamin induces cell cycle-specific apoptosis by modulating the redox status in MDA-MB-231 cells. Eur J Pharmacol 522: 20-29, 2005.

32. de Fátima A, Kohn LK, Antônio MA, de Carvalho JE and Pilli RA: (R)-Goniothalamin: Total syntheses and cytotoxic activity against cancer cell lines. Bioorg Med Chem 13: 2927-2933, 2005.

33. Alabsi AM, Ali R, Ali AM, Al-Dubai SA, Harun H, Abu Kasim NH and Alsalahi A: Apoptosis induction, cell cycle arrest and in vitro anticancer activity of gonothalamin in a cancer cell lines. Asian Pac J Cancer Prev 13: 5131-5136, 2012.

34. Petsophonsakul P, Pompimon $\mathrm{W}$ and Banjerdpongchai $\mathrm{R}$ : Apoptosis induction in human leukemic promyelocytic HL-60 and monocytic U937 cell lines by goniothalamin. Asian Pac J Cancer Prev 14: 2885-2889, 2013.

35. Denizot F and Lang R: Rapid colorimetric assay for cell growth and survival. Modifications to the tetrazolium dye procedure giving improved sensitivity and reliability. J Immunol Methods 89: 271-277, 1986.

36. Oberhammer FA, Hochegger K, Fröschl G, Tiefenbacher R and Pavelka M: Chromatin condensation during apoptosis is accompanied by degradation of lamin $\mathrm{A}+\mathrm{B}$, without enhanced activation of cdc2 kinase. J Cell Biol 126: 827-837, 1994.

37. Shi J, Zheng D, Man K, Fan ST and Xu R: TRAIL: A potential agent for cancer therapy. Curr Mol Med 3: 727-736, 2003.

38. Nagane M, Huang HJ and Cavenee WK: The potential of TRAIL for cancer chemotherapy. Apoptosis 6: 191-197, 2001.

39. Shankar S and Srivastava RK: Enhancement of therapeutic potential of TRAIL by cancer chemotherapy and irradiation: Mechanisms and clinical implications. Drug Resist Updat 7: $139-156,2004$

40. Buchsbaum DJ, Forero-Torres A and LoBuglio AF: TRAILreceptor antibodies as a potential cancer treatment. Future Oncol 3: 405-409, 2007.

41. Krajarng A, Imoto M, Tashiro E, Fujimaki T, Shinjo S and Watanapokasin R: Apoptosis induction associated with the ER stress response through up-regulation of JNK in HeLa cells by gambogic acid. BMC Complement Altern Med 15: 26, 2015.

42. Trivedi R, Maurya R and Mishra DP: Medicarpin, a legume phytoalexin sensitizes myeloid leukemia cells to TRAIL-induced apoptosis through the induction of DR5 and activation of the ROS-JNK-CHOP pathway. Cell Death Dis 5: e1465, 2014

43. Pennati M, Sbarra S, De Cesare M, Lopergolo A, Locatelli SL, Campi E, Daidone MG, Carlo-Stella C, Gianni AM and Zaffaroni N: YM155 sensitizes triple-negative breast cancer to membrane-bound TRAIL through p38 MAPK- and CHOPmediated DR5 upregulation. Int J Cancer 136: 299-309, 2015.

44. Yi L, Zongyuan Y, Cheng G, Lingyun Z, Guilian Y and Wei G: Quercetin enhances apoptotic effect of tumor necrosis factorrelated apoptosis-inducing ligand (TRAIL) in ovarian cancer cells through reactive oxygen species (ROS) mediated CCAAT enhancer-binding protein homologous protein (CHOP)-death receptor 5 pathway. Cancer Sci 105: 520-527, 2014.

45. Yoon MJ, Kang YJ, Kim IY, Kim EH, Lee JA, Lim JH, Kwon TK and Choi KS: Monensin, a polyether ionophore antibiotic, overcomes TRAIL resistance in glioma cells via endoplasmic reticulum stress, DR5 upregulation and c-FLIP downregulation. Carcinogenesis 34: 1918-1928, 2013.

46. Zhang S, Shen HM and Ong CN: Down-regulation of c-FLIP contributes to the sensitization effect of 3,3'-diindolylmethane on TRAIL-induced apoptosis in cancer cells. Mol Cancer Ther 4: 1972-1981, 2005
47. García-García C, Fumarola C, Navaratnam N, Carling D and López-Rivas A: AMPK-independent down-regulation of cFLIP and sensitization to TRAIL-induced apoptosis by AMPK activators. Biochem Pharmacol 79: 853-863, 2010.

48. Lin Y, Liu X, Yue P, Benbrook DM, Berlin KD, Khuri FR and Sun SY: Involvement of c-FLIP and survivin down-regulation in flexible heteroarotinoid-induced apoptosis and enhancement of TRAIL-initiated apoptosis in lung cancer cells. Mol Cancer Ther 7: 3556-3565, 2008.

49. Day TW, Huang S and Safa AR: c-FLIP knockdown induces ligand-independent DR5-, FADD-, caspase-8-, and caspase9-dependent apoptosis in breast cancer cells. Biochem Pharmacol 76: 1694-1704, 2008.

50. Safa AR and Pollok KE: Targeting the anti-apoptotic protein c-FLIP for cancer therapy. Cancers (Basel) 3: 1639-1671, 2011.

51. Safa AR: c-FLIP, a master anti-apoptotic regulator. Exp Oncol 34: 176-184, 2012 .

52. Safa AR: Roles of c-FLIP in apoptosis, necroptosis, and autophagy. J Carcinog Mutagen (Suppl 6): pii: 003, 2013

53. Wilson TR, McLaughlin KM, McEwan M, Sakai H, Rogers KM, Redmond KM, Johnston PG and Longley DB: c-FLIP: A key regulator of colorectal cancer cell death. Cancer Res 67: 5754-5762, 2007.

54. Lee SJ, Noh HJ, Sung EG, Song IH, Kim JY, Kwon TK and Lee TJ: Berberine sensitizes TRAIL-induced apoptosis through proteasome-mediated downregulation of c-FLIP and Mcl-1 proteins. Int J Oncol 38: 485-492, 2011.

55. Murphy AC, Weyhenmeyer B, Noonan J, Kilbride SM, Schimansky S, Loh KP, Kögel D, Letai AG, Prehn JH and Murphy BM: Modulation of Mcl-1 sensitizes glioblastoma to TRAIL-induced apoptosis. Apoptosis 19: 629-642, 2014.

56. Kim SH, Ricci MS and El-Deiry WS: Mcl-1: A gateway to TRAIL sensitization. Cancer Res 68: 2062-2064, 2008.

57. Clohessy JG, Zhuang J, de Boer J, Gil-Gómez G and Brady HJ: Mcl-1 interacts with truncated Bid and inhibits its induction of cytochrome c release and its role in receptor-mediated apoptosis. J Biol Chem 281: 5750-5759, 2006.

58. Ozören N and El-Deiry WS: Cell surface death receptor signaling in normal and cancer cells. Semin Cancer Biol 13: 135-147, 2003.

59. Chen JJ, Mikelis CM, Zhang Y, Gutkind JS and Zhang B: TRAIL induces apoptosis in oral squamous carcinoma cells - a crosstalk with oncogenic Ras regulated cell surface expression of death receptor 5. Oncotarget 4: 206-217, 2013

60. Ren YG, Wagner KW, Knee DA, Aza-Blanc P, Nasoff M and Deveraux QL: Differential regulation of the TRAIL death receptors DR4 and DR5 by the signal recognition particle. Mol Biol Cell 15: 5064-5074, 2004

61. Wei MC, Lindsten T, Mootha VK, Weiler S, Gross A, Ashiya M, Thompson CB and Korsmeyer SJ: tBID, a membrane-targeted death ligand, oligomerizes BAK to release cytochrome $c$. Genes Dev 14: 2060-2071, 2000.

62. Pietenpol JA and Stewart ZA: Cell cycle checkpoint signaling: Cell cycle arrest versus apoptosis. Toxicology 181-182: 475-481, 2002.

63. van Engeland M, Nieland LJ, Ramaekers FC, Schutte B and Reutelingsperger CP: Annexin V-affinity assay: A review on an apoptosis detection system based on phosphatidylserine exposure. Cytometry 31: 1-9, 1998

64. Kuo LJ and Yang LX: Gamma-H2AX - a novel biomarker for DNA double-strand breaks. In Vivo 22: 305-309, 2008.

65. Rogakou EP, Nieves-Neira W, Boon C, Pommier Y and Bonner WM: Initiation of DNA fragmentation during apoptosis induces phosphorylation of H2AX histone at serine 139. J Biol Chem 275: 9390-9395, 2000

66. Ko H, Jeong MH, Jeon H, Sung GJ, So Y, Kim I, Son J, Lee SW, Yoon HG and Choi KC: Delphinidin sensitizes prostate cancer cells to TRAIL-induced apoptosis, by inducing DR5 and causing caspase-mediated HDAC3 cleavage. Oncotarget 6: 9970-9984, 2015.

67. Trang KT, Kim SL, Park SB, Seo SY, Choi CH, Park JK, Moon JC, Lee ST and Kim SW: Parthenolide sensitizes human colorectal cancer cells to tumor necrosis factor-related apoptosisinducing ligand through mitochondrial and caspase dependent pathway. Intest Res 12: 34-41, 2014. 